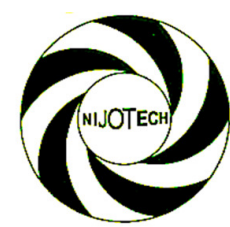

Nigerian Journal of Technology (NIJOTECH)

Vol. 35, No. 1, January 2016, pp. 66 - 70

Copyright(C) Faculty of Engineering, University of Nigeria, Nsukka,

Print ISSN: 0331-8443, Electronic ISSN: 2467-8821

www.nijotech.com

http://dx.doi.org/10.4314/njt.v35i1.11

\title{
THE STUDY OF THERMAL EFFECT ON THE SURFACE PROPERTIES OF GAMMA-ALUMINA SYNTHESIED FROM KANKARA KAOLIN.
}

\author{
S. G. Bawa1 ${ }^{1, *}$, A. S. Ahmed ${ }^{2}$ and P. C. Okonkwo ${ }^{3}$ \\ 1, 2, 3 Department of Chemical Engineering, Ahmadu Bello University, Zaria, Kaduna STATe, NiGERIA. \\ E-mailaddresses.1sgbawa@gmail.com, 2 asahmed2001@yahoo.com,3 chemstprom@gmail.com
}

\begin{abstract}
Gamma alumina is a good material for catalyst support and its surface properties is of great importance. In this study the gamma-alumina $\left(\gamma-\mathrm{Al}_{2} \mathrm{O}_{3}\right)$ synthesized to be used as catalyst support for zeolite catalyst was obtained by calcination of ammonium alum an intermediate product prepared from kaolin which was sourced from Kankara, Katsina, Nigeria. The surface properties were determined using BET technique. BET specific surface area of gamma alumina produced at $825^{\circ} \mathrm{C}$ for soaking time of $3 \mathrm{~h}$ was $120 \mathrm{~m}^{2} / \mathrm{g}$ while at $850^{\circ} \mathrm{C}$ for soaking time of $4 \mathrm{~h}$ the surface area was $140 \mathrm{~m}^{2} / \mathrm{g}$. The pore size and pore volume range from $15 \mathrm{~nm}$ to $25 \mathrm{~nm}$ and $0.5 \mathrm{~cm}^{3} / \mathrm{g} \mathrm{to} 0.8 \mathrm{~cm}^{3} / \mathrm{g}$ respectively. The XRD pattern obtained at $825^{\circ} \mathrm{C}$ and $875^{\circ} \mathrm{C}$ calcination temperatures conformed to the standard pattern of gamma-alumina, having the strong peaks at Bragg angles of $67,46,39$ and $38^{\circ}$. The SEM image showed clearly the plate-like structure of gamma alumina. Thus kankara kaolin is a promising material for the production of gamma alumina.
\end{abstract}

Keywords: Gamma-alumina, kaolin, catalyst, support.

\section{INTRODUCTION}

Alumina is widely used as basic material of catalytic support because of its high chemical inertness, strength and hardness. Gamma-alumina possesses excellent surface area owing to the small particle size, which results in high activity of the surface for a catalyst support [1]. Mesoporous alumina has excellent properties such as highly uniform channels, large surface area and narrow pore size distribution. It has been widely used as adsorbents, catalysts support, and other ceramic applications [2]. Alumina is an important material that can be prepared from bauxite or kaolin in several different phases. The most stable form of alumina is $\alpha$-alumina, which is employed as a ceramic material. Other phases of alumina, known as transitional aluminas are widely used as catalysts, catalytic supports or adsorbents. Among the transitional aluminas, gamma-alumina is the most employed one for applications in catalysis and adsorption, because of its high surface area and good porosity parameters $[3,4]$. Catalyst support is the material, usually a solid with high surface area to which catalyst is affixed. Typical supports include various kinds of carbon, alumina and silica. The reactivity of heterogeneous catalysts and nanomaterial-based catalysts occurs at the surface atoms. Consequently great efforts are made to maximize the surface area of a catalyst by distributing it over the support. Kaolin contains 33-39wt.\% of alumina, therefore, it can be suitable material for production of gamma-alumina because of its abundance and having considerable content of alumina in kaolin structure. More so, the nonavailability of commercial deposit of bauxite being alumina rich mineral in Nigeria led to use of kaolin as the starting material for this study. The two vital parameters in the production of gamma-alumina are the calcination temperature and soaking time. This paper sought to investigate the effect of these two parameters on the textural properties of the gammaalumina produced. It has been reported that porous materials having a surface area value above $100 \mathrm{~m}^{2} / \mathrm{g}$ is considered having a high surface area and is a potential material for catalyst support $[5,6,7]$.

Single alum (Aluminium sulphate) was produced from Kankara kaolin which was associated with difficulties in filtering the crystals form and the process involved external heating source [8]. The difficulties of filtering the alum crystal forms fromed was overcome by the use of excess acid in the reaction medium and was 
reported [9]. Partial dealumination techniques using novel method had been carried out for the synthesis of zeolite from Kankara kaolin as reported by previous studies [10]. In that studies the filtrate of the dealumination being alum was discarded as waste material. Gamma alumina was synthesized at a single temperature from Kankara kaolin [11]. Precipitation of Al (hydr)oxide with ammonia from acid-leachates of calcined kaolin [12].

Despite all the reported studies on Kankara kaolin, no work had been reported on the details surface parameter analysis as dependent on temperature and time being the key parameters in heat treatment reaction. As such, this study sough to establish the effect of temperature and soaking time on the thermal treatment of ammonium alum produced from Kankara kaolin through novel method (which does not involve external heating) on the surface parameters which is a unique property of a porous material.

The Brunauer-Emmett-Teller (BET) equation can be used to determine volume of gas required for monolayer coverage, for surface parameter determination of porous material, $v_{m}$ for cases of multilayer adsorption. The surface area is calculated by multiplying by a monolayer packing constant for the adsorbed gas. For a porous material, the surface area determined experimentally depends on the size of the adsorbed molecule relative to the size of the pores. The specific surface area per unit mass $S_{M}$ is given by:

$$
S_{M}=\frac{N_{A} v_{m} A_{m}}{V_{m o l} M_{s}}
$$

where $N_{A}$ is Avogadro's number, $A_{m}$ is the area occupied by one adsorbate molecule $\left(16.2 \times 10^{-20} \mathrm{~m}^{2}\right.$ for $\mathrm{N}_{2}$ and $19.5 \times 10^{-20} \mathrm{~m}^{2}$ for $\mathrm{Kr}$ ), $V_{m o l}$ is the volume of mole of gas at STP of $V_{m}$, and $M_{s}$ is the mass of the sample [13].

$$
v_{m}=\frac{1}{S+I}
$$

Where $\mathrm{S}$ is the slope $\mathrm{I}$ is the intercept

\section{MATERIALS AND METHODS}

The starting material was kaolin sourced from Kankara town of Katsina state, Nigeria. A wellestablished method of wet beneficiation process [9 11 14] was employed to obtain purified kaolin. The beneficiated kaolin was calcined at $750^{\circ} \mathrm{C}$ for 2 hours to activate the kaolin as reported in previous studies $[9,14]$. For a run of dealumination step of $50 \mathrm{~g}$ metakaolin $185 \mathrm{ml}$ of water was added and stir to form metakaolin slurry, $167 \mathrm{ml}$ of $96 \mathrm{wt} \%$ was added. After about $15 \mathrm{mins} 288 \mathrm{ml}$ of distilled water was added to quench the reaction. The solution obtained during dealumination was filtered with high vacuum pump. Ammonium sulfate was used as the salting agent to crystallize the ammonium alum at $0^{\circ} \mathrm{C}$ for $6 \mathrm{hrs}$. The ammonium alum crystals were filtered from the mother liquor and then dried at $250^{\circ} \mathrm{C}$ for $6 \mathrm{hrs}$. The ammonium alum was calcined at a constant soaking time of $3 \mathrm{hrs}$ for $825^{\circ} \mathrm{C}, 850^{\circ} \mathrm{C}$ and $875^{\circ} \mathrm{C}$. And at constant calcination temperature of $850^{\circ} \mathrm{C}$ soaking time of $1,2,3$, and 4 hours were varied. The specific surface area, average pore size and pore volume were determined using the Brunauer-Emmett-Teller (BET) technique by $\mathrm{N}_{2}$ adsorption at $-196^{\circ} \mathrm{C}$ using Tristar 3000 micrometrics equipment. at the University College London (UCL). The X-ray diffraction patterns were obtained using Empyreal, PANalytical diffractometer employing $\mathrm{Cu} \quad \mathrm{K} \alpha$ radiation $(\lambda=0.154 \mathrm{~nm})$. at the National Geoscience Research Laboratories (NGRL), Kaduna. The Scanning Electron Microscopy (SEM) image of the gamma alumina at $850^{\circ} \mathrm{C}$ and soaking time of $3 \mathrm{~h}$ was carried out. Minipal 4 machine was used to ascertain the chemical compositions of the gamma alumina through XRF analysis.

Table 1: Chemical composition of as-synthesized and commercial gamma alumina

\begin{tabular}{ccc}
\multicolumn{3}{c}{ commercial gamma alumina } \\
\cline { 2 - 3 } Oxides & \multicolumn{2}{c}{ Gamma-alumina } \\
\cline { 2 - 3 } & As-synthesized & Commercial \\
\hline $\mathrm{Al}_{2} \mathrm{O}_{3}$ & 85.02 & 89.80 \\
$\mathrm{SO}_{3}$ & 4.76 & 2.54 \\
$\mathrm{SiO}_{2}$ & $\mathrm{ND}^{*}$ & 0.03 \\
$\mathrm{Fe}_{2} \mathrm{O}_{3}$ & 2.67 & 0.17 \\
LOI & 5.16 & 5.21 \\
Other oxides & 2.19 & 2.25 \\
\hline
\end{tabular}

*ND: Not detected

\section{RESULTS AND DISCUSSION}

The gamma-alumina was lower in alumina content when compared with the commercial alumina by $4.78 \%$ as shown in Table 1 . The silica content in the prepared gamma-alumina was below detection while it was detected in the commercial gamma-alumina. The $\mathrm{Fe}_{2} \mathrm{O}_{3}$ in the prepared gamma-alumina was higher in value when compared to the commercial alumina, this might be attributed to the source of the product being a natural mineral.

BET isothermal plots are as shown in Figure $1(a-f)$, from the model equations obtained from the plot, the values of the slope and intercept were used to evaluate volume of gas $\left(v_{m}\right)$ required for multilayer adsorption as shown in Equation 2 which was in conformity as reported previously [13]. The value of $\mathrm{V}_{\mathrm{m}}$ was inserted in Equation 1, to obtain the specific surface area of each of the gamma-alumina obtained at different temperatures and times.

Vol. 35, No. 1, January 2016 


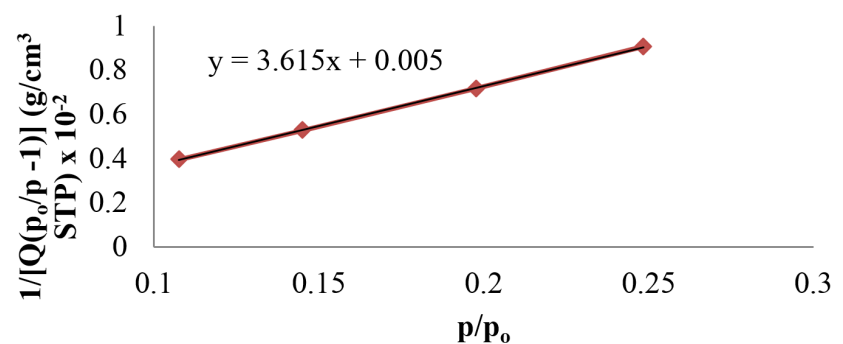

(a)

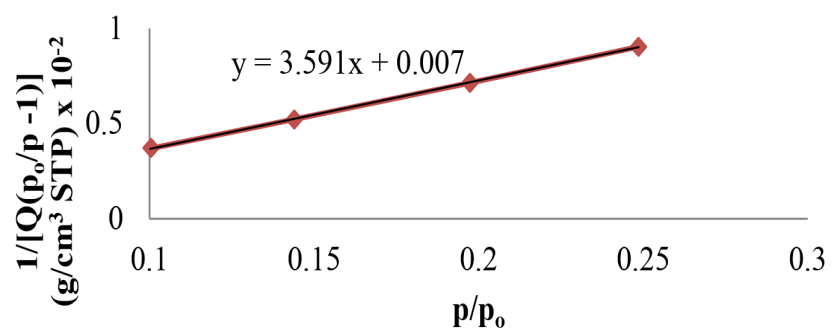

(c)

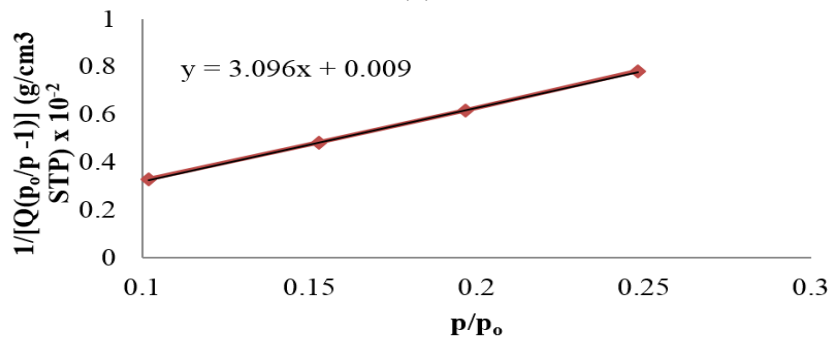

(e)

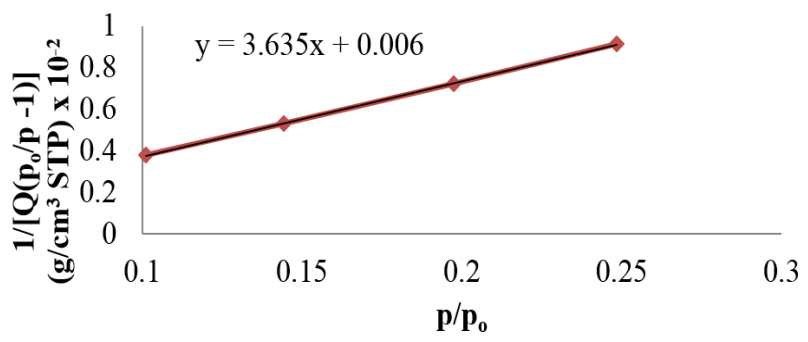

(b)

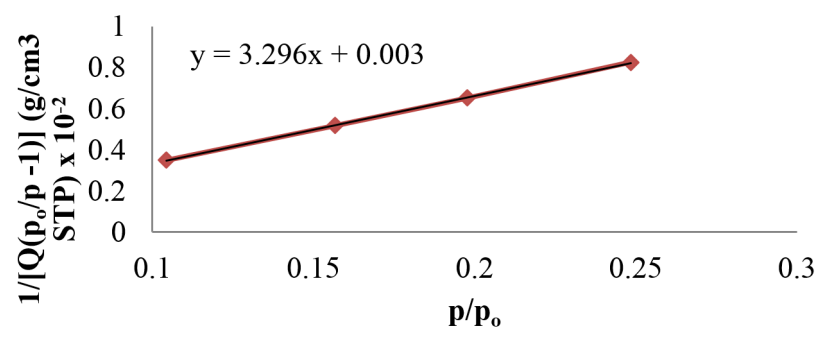

(d)

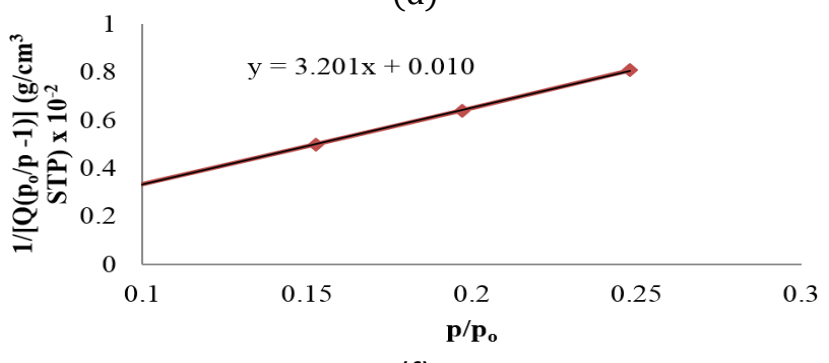

(f)

Figure 1: BET isothermal plots, (a) 825으 for 3 hrs; (b) $850^{\circ} \mathrm{C}$ for $1 \mathrm{hr}$; (c) $850^{\circ} \mathrm{C}$ for $2 \mathrm{hrs;}$ (d) $850^{\circ} \mathrm{C}$ for $3 \mathrm{hrs}$ (e) $850{ }^{\circ} \mathrm{C}$ for 4 hrs (f) $875^{\circ} \mathrm{C}$ for 3 hrs

At a constant soaking time of 3 hours, as the calcination temperature increased the specific surface area of the gamma-alumina also increased as shown in Figure 2. But the increase was more rapid between $825^{\circ} \mathrm{C}$ and $850^{\circ} \mathrm{C}$, beyond which the increase in the specific surface area with respect to the calcination temperature became gradual. The highest specific surface area value of the gamma-alumina was obtained at a calcination temperature of $875^{\circ} \mathrm{C}$. The increase in the surface area as the thermal energy increases could be attributed to the liberation of the $\mathrm{SO}_{3}$ from the collapse structure of crystalline aluminum sulfate to yield a transitional alumina.

Gradual increase in specific area was observed as the soaking time increased from 1 to $2 \mathrm{~h}$ as shown in Figure 3 at a constant calcination temperature of $850^{\circ} \mathrm{C}$. A more rapid steady increase was observed as the soaking time increased from 2 to $4 \mathrm{~h}$. Increase in soaking time translate to increase in the thermal energy in the system as such more of the chemical bonds present in the intermediate product (alum) to liberate $\mathrm{SO}_{3}$ gas and leaving the solid product, which is alumina. It could be infered from Figure 3, that for the first hour, most of the thermal energy in the form of heat was utilise for weaken of the existing chemical bonds, while one hour soaking time, pronouced liberation of the gaseous product occurred which translated to the increase in the specific surface area.

Figure 4 shows the effect of calcination temperature on the average pore diameter (size) and pore volume of the gamma-alumina developed. The optimum range of the average pore size was obtained between $840^{\circ} \mathrm{C}$ and $850^{\circ} \mathrm{C}$. Beyond $850^{\circ} \mathrm{C}$ the pore size began to decrease, this may be attributed to the collapse of larger pore particle to smaller pore particle possessing larger surface area. It is generally believed that the smaller the pore sizes of a porous material the higher its surface area. The pore volume of the gaamaalumina increased as the calcination temperature incresed from $825^{\circ} \mathrm{C}$ to an optimum temperature of about $850^{\circ} \mathrm{C}$. Decrease in the pore volume was observed after $850{ }^{\circ} \mathrm{C}$ as shown in Figure 4. 


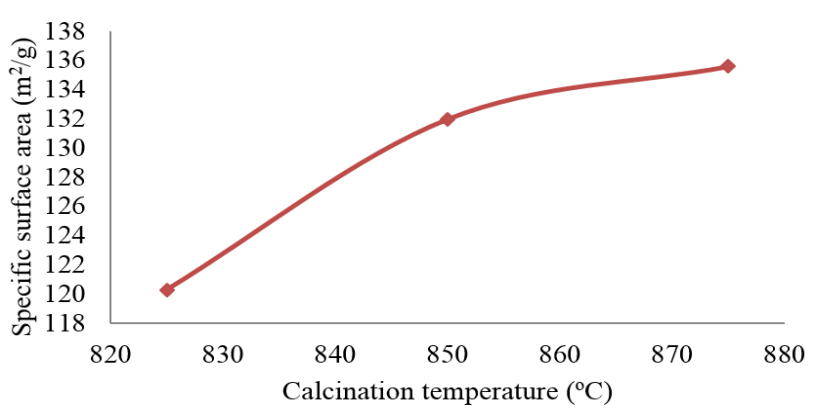

Figure 2: Variation of specific surface area with calcination temperature at constant soaking time of $3 \mathrm{~h}$.

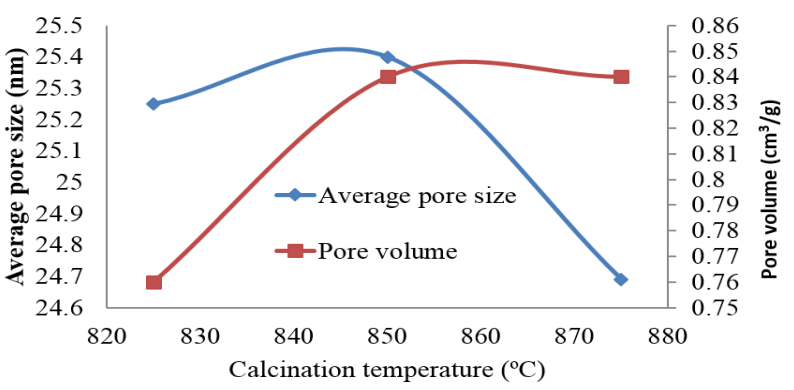

Figure 4: Variation of average pore size pore volume with calcination temperature at constant soaking time of $3 \mathrm{~h}$

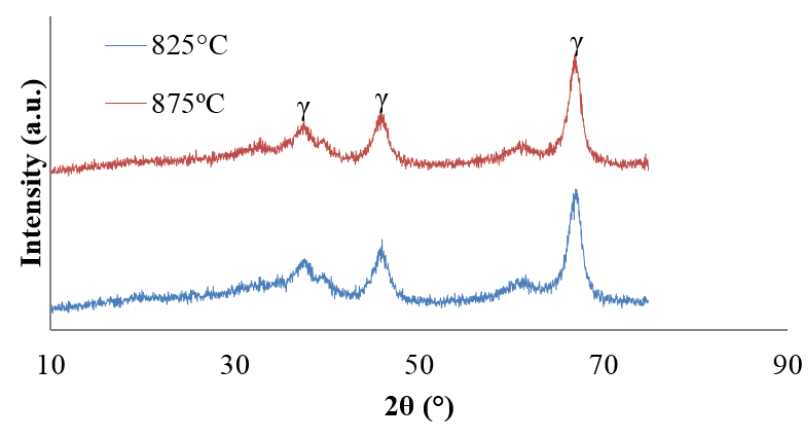

Figure 6: XRD patterns of developed gamma-alumina

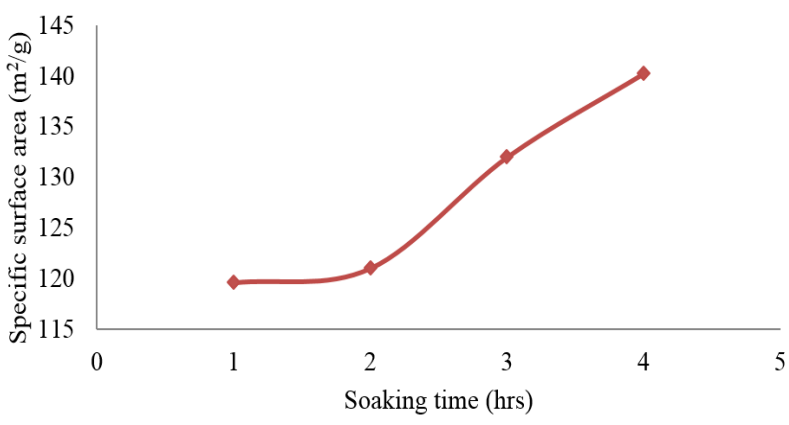

Figure 3: Variation of specific surface area with soaking time at constant constant temperature of $850^{\circ} \mathrm{C}$

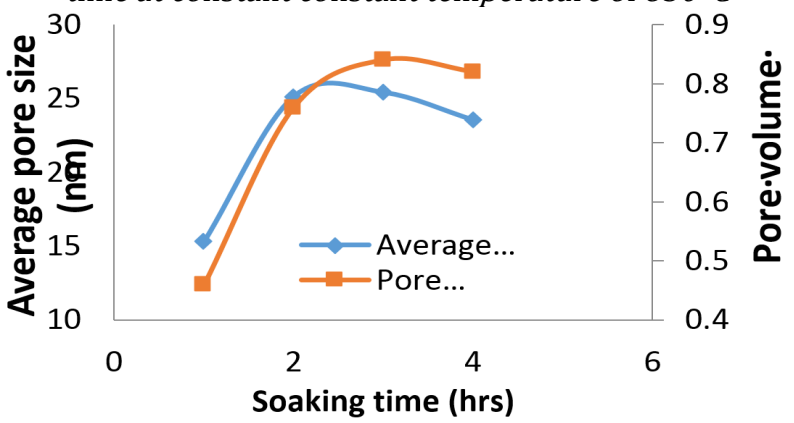

Figure 5: Variation of average pore size and pore volume with soaking time at constant temperature of $850^{\circ} \mathrm{C}$

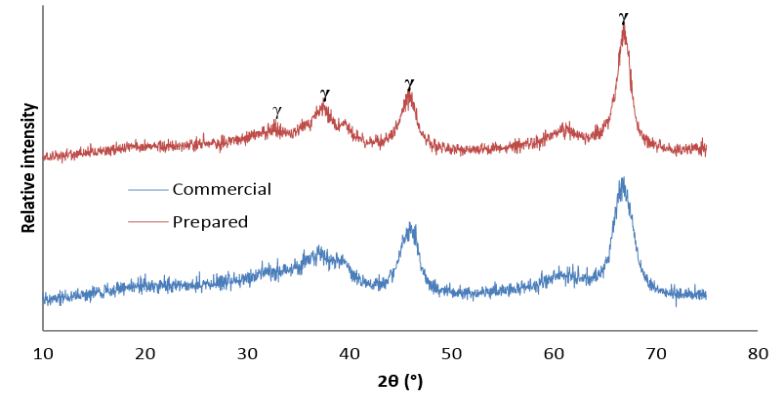

Figure 7: XRD pattern of commercial and prepared gamma-alumina

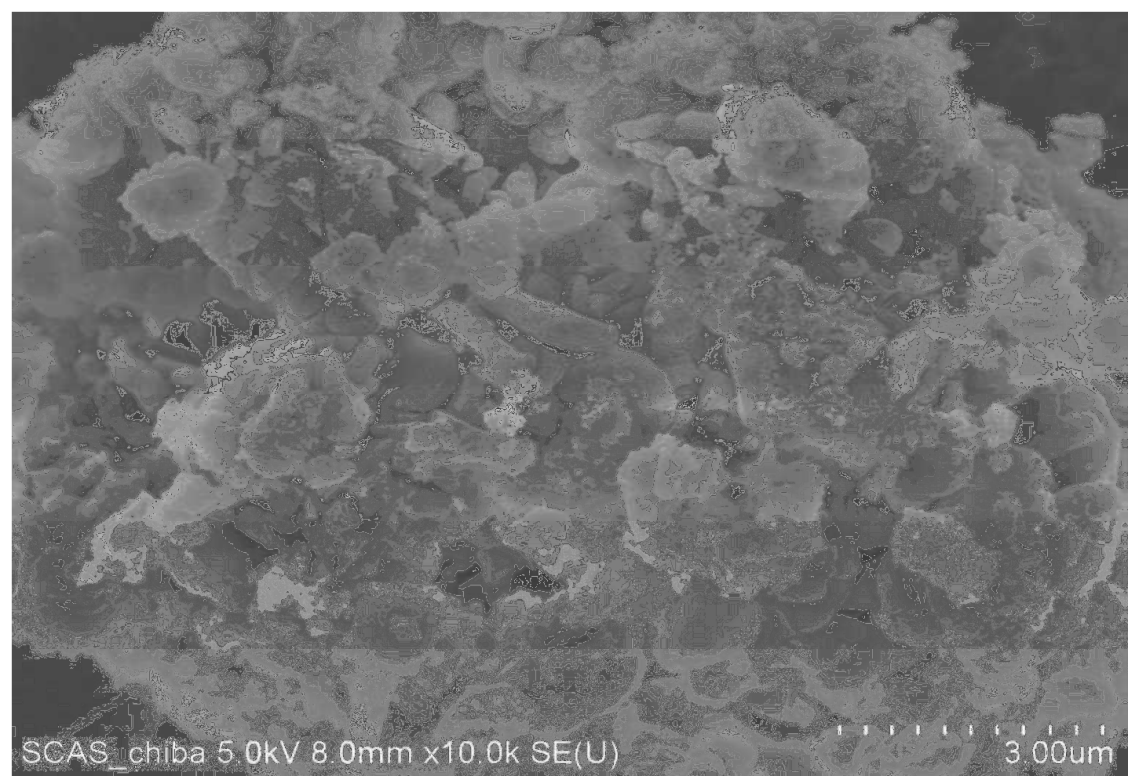

Figure 8: SEM image of gamma alumina synthezied fro Kankara kaolin 
Soaking time of 3 hours was the optimum with respect to the pore volume of the gamma-alumina developed. The average pore size of the gamma-alumina developed increased with soaking time between 1 and $2 \mathrm{~h}$ as shown in Figure 5. The average pore size began to decrease but in a gradual manner beyond the soaking time of $2 \mathrm{~h}$. The optimum soaking time range is between 2 and $3 \mathrm{~h}$.

From the diffractogram obtained from XRD analysis, it showed that gamma-alumina was produced as shown in Figure 6. The pattern was similar to earlier studies reported [11 12].

A close similarity was observed between the XRD patterns of the developed gamma-alumina and the commercial gamma-alumina produced from bauxite (Figure 7). The standard peaks of gamma-alumina were present in the XRD pattern for both the commercial and developed gamma-alumina which occurred at the same position of Bragg angles.

The morphology of the gamma-alumina synthesized is as shown in Figure 8, it hexagonal shape associated with gamma-alumina was observed. The large surface area recorded must have been due to the clear platelet structure of $\gamma$-alumina (Figure 8) as distinct from the other transition aluminas.

\section{CONCLUSION}

The specific surface area of the gamma-alumina developed from Kankara kaolin was good enough for support materials for metal catalysts such as platinium. Specific surface area of above $100 \mathrm{~m}^{2} / \mathrm{g}$ was obtained. The average pore size is large enough to prevent diffusion resistance of both reactants and products. Calcination temperature of $850^{\circ} \mathrm{C}$ for 4 soaking time gave the highest surface area value. The optimum values of the average pore size and pore volume were obtained at calcination temperature of $850 \stackrel{\circ}{\circ} \mathrm{C}$ for $3 \mathrm{~h}$ soaking time. The gamma-alumina produced was similar to the commercial gammaalumina.

\section{REFERENCES}

[1] Itoh, T., Uchida, T., Matsubara, I., Izu, N., Shin, W., Miyazaki, H., Tanjo, H. and Kanda, K. "Preparation of $\gamma$-alumina large grain particles with large specific surface area via polyol synthesis", Elsevier: Ceramic International; article in press.

[2] Pan, F., Lu, X., Wang, T., Wang, Y., Zhang, Z., Yan, Y., and Yang, S. "Synthesis of Large-Mesoporous $\gamma-\mathrm{Al}_{2} \mathrm{O}_{3}$ from Coal-Series Kaolin”, Materials Letters, Vol. 91, 2013, pp 136-138.

[3] Sifontes, A.B., Urbina, M., Fajardo, F., Melo, L., Garcia, L., Mediavilla, M., Carrion, N., Brito, J.L., Hernandez, P., Solano, R., Mejias, G. and Quintero, A. "Preparation of $\gamma$-Alumina foams of High Surface Area Employing the Polyurethane Sponge Replica Method", Journal of Latin American Applied Research, Vol. 40, 2010, pp 185-191.

[4] Hosseini, S. A., Niaei, A. and Dariush, S. "Production of $\gamma-\mathrm{Al}_{2} \mathrm{O}_{3}$ from Kaolin", Open Journal of Physical Chemistry Vol. 1, 2011, pp 23-27.

[5] Salahudeen, N. Development of Catalyst Support Material from Pindiga Bentonitic Clay. MSc. Thesis Department of Chem. Eng., ABU, Zaria, March, 2012.

[6] Coelho, A.C.V., Santos, H., Kiyohara, P.K., Marcos, K.N.P. and Santos, P. "Surface area, crystal morphology and characterization of transition alumina powders from a new gibbsite precursor", Journal of Material Research, Vol. 10, Number 2, 2007, pp 183-189.

[7] Wefers, K. and Misra, C. "Oxides and Hydroxides of Alumina" Alcoa Technical paper 19, Revised, Aluminum Company of America, Pennsylvania, 1987, pp 54-58.

[8] Aderemi, B.O., Ahmed, A.S. and Abdul B.D (2006). "Production of Alum from Kankara Clay", Journal of Nigeria Society of Chemical Engineers. Vol. 21, Number 2, 2006 pp 120-124.

[9] Edomwonyi-Otu, L. and Aderemi, B.O. "Alums from Kankara Kaolin" Journal of Research in Engineering. Vol. 6, Number 1, 2009, pp 105-111.

[10] Ajayi, A.O., Atta, A.Y., Aderemi, B.O. and Adefila, S.S. "Novel Method of Metakaolin Dealumination", Journal of Applied Sciences Research, Vol. 6, Number 10, 2010, pp 1539-1546.

[11] Aderemi, B.O. and Hameed, B.H. "Alumina from Kaolin - Extraction and Characterization" Nigerian Metallurgical Society Conference, November, 2011, pp. 75-80.

[12] Yang, H., Liu, M. and Ouyang, J. "Novel synthesis and characterization of nanosized $\gamma-\mathrm{Al}_{2} \mathrm{O}_{3}$ from kaolin", Applied Clay Science, Vol. 47, Number 3, pp 438-443.

[13] Reed, S. J. Introduction to the Principles of Ceramic Processing, John Wiley and Sons, New York, 1988.

[14] Ahmed, A.S. and Bawa, S.G. "Development of Large Surface Area Alumina from Kankara Kaolin for Zeolite Support", Poster presentation at International Symposium in Zeolite and MicroPorous Crystals (ZMPC), held at Hiroshima, July, 2012. 